\title{
IDENTIFIKASI SEDERHANA METABOLIT SEKUNDER TUMBUHAN SASALADAHAN (Peperomia pellucidan (L). Kunt)
}

\author{
Ermi Abriyani, M.Si \\ Program Studi Farmasi, Fakultas Teknologi dan Ilmu Komputer, Universitas Buana Perjuangan \\ Karawang (ermi.abriyani@ubpkarawang.ac.id)
}

\begin{abstract}
This study aims to identification of Peperomia pellucida L. Kunt plant. Steps being taken include phytochemical test, extraction, and identification of extraction from ethanol extract. The research is to provide information on indentification of secondary metabolite from ethanol extract.
\end{abstract}

\begin{abstract}
ABSTRAK
Penelitian ini bertujuan untuk menentukan identifikasi dari tumbuhan Peperomia pellucida (L) Kunt. Beberapa tahapan yang dilakukan antara lain; mengecek fitokimianya, ekstraksi dan menentukan identifikasi dari ekstrak etanol. Hasil penelitian memberikan informasi tentang senyawa metabolit sekunder dari etanol ekstrak.

Kata kunci: identifikasi, Peperomia pellucida (L) Kunt, metabolit sekunder

\section{Pendahuluan}

Indonesia merupakan negara kepulauan yang memiliki keanekaragaman tumbuhan dan sumber daya hayati dari hutan tropis dan memiliki keanekaragaman ekosistem dan dikenal sebagai negara megabiodiversitas kedua setelah Brazil. Keanekaragaman hayati tersebut merupakan aset bangsa sebagai sumber devisa negara. Disamping sebagai devisa, tumbuhan adalah sumber bahan kimia hayati (chemical resourches) yang terus menerus berproduksi sepanjang tahun melalui proses alami, sehingga setiap spesies dapat memproduksi bahan kimia hayati berguna yang sangat bergantung pada lingkungan tumbuhan tersebut (Ersam, 2005). Keanekaragaman hayati terbesar, berpotensi dalam pengembangan obat herbal yang berbasis pada tumbuhan obat dalam usaha kemandirian dibidang kesehatan. Beberapa senyawa yang telah terbukti sebagai senyawa aktif antara lain golongan metabolit sekunder seperti santon, kumarin, flavonoid, terpenoid, alkaloid dan lain-lain.
\end{abstract}


Tumbuhan sasaladahan (Peperomia pellucida (L). Kunt) atau yang juga dikenal dengan tumbuhan suruhan merupakan tumbuhan semak yang tersebar luas diseluruh wilayah Indonesia. Tumbuhan ini dapat digunakan sebagai pereda antinyeri pada penyakit rematoid atritis, antikanker, dan anti bakteri.

Dari penelitian sebelumnya sudah dilaporkan beberapa penelitian dari tumbuhan suruhan seperti; aktifitas antioksidan tumbuhan suruhan, Peperomia Pellucida (L). Kunth (Sitorus, Momuat dan Katja, 2013) sehingga peneliti mencoba melakukan penelitian terhadap tumbuhan suruhan atau sasaladahan yang dikumpulkan dari area pemukiman kabupaten karawang dengan mengidentifikasi metabolit sekunder yang dilakukan secara sederhana.

Berdasarkan pendekatan khemotaksonomi bahwa kandungan kimia dalam satu famili mempunyai model molekul yang sejenis, dan kandungan kimia dalam satu spesies pada umumnya sama maka permasalahan pada penelitian ini adalah, apakah pada tanaman suruhan, peperomia pellucid L.Kunt ini akan memberikan informasi mengenai adanya metabolit-metabolit sekunder.

\section{Metode penelitian}

Peralatan yang digunakan adalah peralatan gelas yang umum dipakai pada penelitian kimia organik bahan alam, seperangkat alat destilasi pelarut, rotary evaporator Heidolph WB 2000, oven, pompa vakum, plat KLT (Silika gel Merk $60 \mathrm{GF}_{254}$ ), kolom kromatografi biasa, kertas saring, lumpang porselen, pipet tetes, pipa kapiler, bejana kromatografi, Lampu UV model UV GL - 58 UV 254 dan 360 nm, microplate reader, pH meter. Bahan yang digunakan adalah : n-hekasan, etil asetat, metanol, asam klorida p.a, aquades, serbuk magnesium, etil asetat, amoniak p.a, $\mathrm{AlCl}_{3}$, asam asetat, natrium hidroksida, asam sulfat pekat, $\mathrm{FeCl}_{3}$, natrium asetat, asam borat, dapar fosfat $\mathrm{pH}$ 6,9, DMSO, p-nitrophenyl- $\alpha$-D-glukopiranosida, natrium karbonat, a-glukosidase. Silika gel Merk $60 \mathrm{GF}_{254}$ (230-400 mesh), sedangkan kromatografi lapis tipis (KLT) mengunakan plat KLT Kiessel gel 60 GF 254. Pereaksi Meyer digunakan untuk identifikasi alkaloid, pereaksi Lieberman Burchard untuk identifikasi terpenoid dan steroid, Sianoda tes untuk identifikasi flavonoid dan $\mathrm{FeCl}_{3}$ untuk identifikasi fenolik . 


\section{Uji Fitokimia sampel tumbuhan sasaladahan, Peperomia pullucida L. Kunt}

\section{Pemeriksaan Alkaloid}

Empat gram sampel ditambahkan $10 \mathrm{~mL}$ kloroform dan $10 \mathrm{~mL}$ ammonia. Larutan tersebut disaring ke tabung reaksi dan filtrate di tambahkan 10 tetets $\mathrm{H}_{2} \mathrm{SO}_{4} 2 \mathrm{~N}$. Campuran dikocok dan didiamkan sampai terbentuk dua lapisan. Lapisan atas dipindahkan ke dalam tabung reaksi yang masing-masing diisi $\pm 1 \mathrm{~mL}$. Kemudian ditambahkan pereaksi Mayer, jika didapatkan endapan putih mengindikasikan adanya alkaloid dalam sampel

\section{Pemeriksaan Flavonoid}

Pemeriksaan flavonoid digunakan metoda Sianidin test, sebanyak 5 gram sampel tanaman suruhan yang sudah dihaluskan ditambah $20 \mathrm{~mL}$ methanol, kemudian dididihkan dan disaring selagi panas. Ambil ekstrak methanol dan uapkan, setelah kering residu dilarutkan dengan etil asetat dan disaring. Filtratnya diuapkan dan sisanya dilarutkan dalam etanol, kemudian tambahkan asam klorida pekat dan bubuk magnesium, terbentuknya warna orange sampai merah menunjukkan adanya flavonoid (kecuali untuk flavon).

\section{Pemeriksaan Saponin}

Bahan simplisia dan ekstrak1 g ditambahkan $100 \mathrm{ml}$ air panas, dididihkan selama 15 menit kemudian disaring. Filtrat sebanyak $10 \mathrm{ml}$ dalam tabung reaksi dikocok 166ellucid selama 10 detik dan diamkan selama 10 menit. Bahan positif mengandung saponin bila terbentuk buih yang mantap selama tidak kurang dari 10 menit setinggi $1 \mathrm{~cm}$ dan buih tidak hilang ketika ditambah $\mathrm{HCl} 2 \mathrm{~N}$.

\section{Pemeriksaan Tanin}

Bahan simplisia dan ekstrak1 g ditambahkan $100 \mathrm{ml}$ air panas, dididihkan selama 15 menit kemudian disaring. Filtrat sebanyak $5 \mathrm{ml}$ direaksikan dengan larutan $\mathrm{FeCl}_{3} 1 \%$. Dalam tabung lain, $5 \mathrm{ml}$ sampel ditambahkan larutan gelatin. Bahan positif mengandung tannin jika timbul warna hijau violet pada penambahan $\mathrm{FeCl}_{3}$ dan terbentuk endapan pada penambahan larutan gelatin.Untuk pemeriksaan tannin galat dan katekat dilakukan dengan cara berikut. Filtrat 
ditambahkan pereaksi Steany, kemudian dipanaskan dalam tangas air. Bahan positif mengandung katekat jika terbentuk endapan merah muda.

\section{Pemeriksaan Steroid/Triterpenoid}

Bahan simplisia dan ekstrak1 gram dimaserasi dengan 25 ml eter selama 2 jam kemudian disaring. Filtrat sebanyak $5 \mathrm{ml}$ diuapkan dalam cawan penguap, kedalam residu ditambahkan 2 tetes asam asetat anhidrat kemudian ditambah 1 tetes asam sulfat pekat. Bahan positif mengandung steroid/triterpenoid jika terbentuk warna ungu - biru/hijau.

\section{Hasil Dan Pembahasan}

\section{Pengolahan sampel}

Sampel yang digunakan sebaiknya mempunyai kadar air kurang dari 10\% (Winarno, 2008).

Kadar air yang dihasilkan dari sampel suruhan, Peperomia pellucida (L) Kunt adalah

Berat sampel basah $\quad=2500$ gram

Berat sampel kering $\quad=200$ gram

$\%$ kadar air dalam sampel =

$$
\begin{gathered}
\frac{(\text { Berat sampel basah }- \text { berat sampel kering) } \times 100}{\text { Berat sampel basah }} \\
\quad=\frac{(2500 \mathrm{~g}-200 \mathrm{~g}) \times 100 \%}{2500 \mathrm{~g}}=92 \%
\end{gathered}
$$

Berdasarkan dari pengujian kadar air maka sampel Peperomia pellucida (L). Kunt dapat digunakan dan dilanjutkan untuk ekstraksi sampel.

\section{Uji Fitokimia}

Berdasarkan dari uji fitokimia sampel suruhan, Peperomia pellucida (L).Kunt dihasilkan seperti table dibawah ini. 
Tabel 4.1 Hasil uji fitokimia daun suruhan

\begin{tabular}{lllc}
\hline No. & Kandungan Kimia & Pereaksi & Hasil Uji \\
\hline 1. & Flavonoid & Sianidin test & + \\
2. & Fenolik & $\mathrm{FeCl}_{3}$ & + \\
3. & Saponin & $\mathrm{H}_{2} \mathrm{O}$ & + \\
4. & Terpenoid & Liebermann-Burchard (LB) & + \\
5. & Steroid & Liebermann-Burchard (LB) & + \\
\hline
\end{tabular}

Keterangan : (+) = ada, (-) = tidak ada

Dari data diatas dapat diketahui bahwa tumbuhan suruhan, peperomia pellucid (L)Kunt. mengandung senyawa metabolit sekunder, yaitu flavonoid, fenolik, saponin, terpenoid, steroid.

\section{Penutup}

Berdasarkan dari hasil penelitian dapat disimpulkan bahwa tumbuhan suruhan mempunyai kadar air yang kurang dari 10\% yakni 5,04 \% sehingga dapat dilanjutkan untuk perlakuan ekstraksi sampel. Dalam perlakuan fitokimia tumbuhan suruhan mengandung flavonoid, fenolik, saponin, terpen dan steroid. Perlunya dilakukan penelitian lebih lanjut dalam penentuan bioaktivitas dari kandungan metabolit sekunder pada tumbuhan Peperomia pellucidan (L) Kunt.

\section{Daftar pustaka}

Aziba, P.I., et al, 2010, Analgesic Activity of Peperomia pellucid Aerial Parts in Mice. Fitoterapia, Vol. 72, Hal. 57-58

Cao Hu Jiao, 2011, Philipine Medicinal Plant ; Pansir-pansitan, Manila: Manila Medical Society

Djauhariya E., Hernani, 2004, Ghulma Berkhasiat Obat, Jakarta, Penebar Swadaya. 
Majumder, P., Abraham, P., V., Satya, 2011, Review Article; Ethno-medicinal, phytochemical and Pharmacological review of an amazing medicinal herb $\underline{\text { Peperomia }}$

Moradi-Afrapoli, F., Asghari, B., Saeidnia, S., 2012, In-vitro $\alpha$-glukosidase inhibitory activity of phenolic Constituents from Aerial Parts of Polygonum hyrcanicum, DARU Journal of Pharmaceutical Sciences, 20: 37.

Sitorus, Erwin., Momuat dan Katja, 2013, Aktifitas antioksidan tumbuhan Suruhan (Peperomi pellucida (L.) Kunth, Jurnal Ilmiah Sains, Vol. 13 No. 2; 80-85

Tarigan, I.M. br, S. Bahri dan A. Saragih, 2012, aktifitas antihiperurisemia ekstrak etanol herba suruhan (Peperomia pellucida (L.) Kunt) padan mencit jantan. Journal of Pharmaceutical and pharmacology $1(1) ; 37-43$

Wei, L.S., W. Wee, J.Y.F Siong \& D.F. Syamsumir, 2011, Characterization of anticancer, antimicrobial, antioxidant properties and chemical compositions of (Peperomia pellucid extract. Acta medica Iranica 49(10); 670-674 